\title{
Identification of prevailing storm runoff generation mechanisms in an intensively cultivated catchment
}

\author{
David Zumr*, Tomáš Dostál, Jan Devátý \\ Department of Irrigation, Drainage and Landscape Engineering, Faculty of Civil Engineering, Czech Technical University in Prague, \\ Thákurova 7, 16629, Prague 6, Czech Republic. \\ *Corresponding author. Tel.: +420 224354745. E-mail: david.zumr@fsv.cvut.cz
}

\begin{abstract}
The fact that flash floods initiated in arable catchments are often accompanied by massive sediment and nutrient loads often leads to the assumption that surface runoff is the principle pathway by which runoff reaches watercourses. On the basis of an evaluation of several rainfall-runoff events in a representative agricultural catchment, we show that runoff from cultivated land may be generated in a way similar to that seen on forested slopes, where shallow subsurface runoff is the predominant pathway by which runoff makes its way to watercourses in most runoff events. To identify the predominant runoff pathway, we employed a combination of turbidity measurements and stream discharge data. Suspended sediment flux, a newly introduced index representing the ratio between precipitation duration and total sediment yield, and direction of the discharge-turbidity hysteresis loops were proposed as reflective indicators of the frequency of runoff via different pathways.

In our study, most of the events initiated by rainstorms of various intensities and durations resulted in rapid increases in stream discharge. Although we observed temporal variability of topsoil properties attributable to seasonal weather changes and agricultural activities, e.g. bulk density and porosity, runoff generation was mainly driven by precipitation characteristics and the initial catchment saturation.
\end{abstract}

Keywords: Shallow subsurface runoff; Surface runoff; Rainfall-runoff; Soil erosion; Suspended solids transport; Agriculture watershed.

\section{INTRODUCTION}

The IPCC has cited more frequent occurrences of intensive storm events as evidence of climate change in Central Europe (Kovats et al., 2014). Recent hydrological research has therefore focused on studies of rainfall-runoff processes, though far fewer studies have investigated cultivated agricultural catchments than forested catchments. Rainfall-runoff processes in cultivated catchments are of great importance, as many fields are situated on slopes, and because arable land is one of the main non-point sources of solid particles, nutrients, fertilizers and herbicides in rivers and lakes (Dorioz and Ferhi, 1994).

The runoff response of a catchment is determined by climate, size, topography, land use and soil parameters. Infiltration regime and runoff routing depend on many factors at various spatial and temporal scales. Runoff can make its way to watercourses via several pathways including overland flow, subsurface stormflow, pipeflow or groundwater flow (Jones, 1997). The hydrology of cultivated catchments has specific features. The temporary, variable properties of periodically cultivated soils are a crucial factor that must be taken into account in order to understand flow processes in agriculture catchments (Pare et al., 2011). Bachmair et al. (2012) and Birkel et al. (2011) have suggested that there is also seasonal variability of the catchment water storage and runoff generation on grasslands and forested hillslopes. Soil structure is a property that is often considered to be static rather than dynamic. This could be a reasonable assumption for extensively compacted land or subsoil, but not for regularly tilled topsoil layers. Anthropogenic effects, e.g. overuse of heavy machinery, tillage, ploughing and harvesting, and also natural processes such as rapid vegetation and root growth, edaphon activity, the kinetic energy of raindrops, freezing, thawing, etc., cause recurrent cycles of topsoil loosening, compaction and surface sealing (Alaoui et al., 2011). The gradual deformation of the soil structure within a growing season causes a reduction in the volume and the connectivity of interaggregate voids. Eroded fine particles clog the macropores and preferential pathways, and infiltration capacity and soil water storage decrease. Originally, connected large pores normally serve as a quick bypass for infiltrating water. Therefore, based on the state of the topsoil structure and subsoil permeability, one can expect different water runoff mechanisms; ranging from deep percolation and shallow subsurface lateral flow to surface runoff to play a greater or lesser role in runoff generation. This phenomenon does not necessarily have a significant effect on the soil water regime in soils where the subsoil contains a developed macropore network due to soil fauna and roots (Roulier et al., 2002; Steenhuis et al., 1988).

Stormflow generation at the hillslope scale has been widely studied since the 1960s (Whipkey, 1965), mainly on steep forested slopes, where subsurface runoff contributes greatly to the total runoff due to root channels, old root holes, and bio-pores. Various methods based on detailed hillslope inspection and dye tracer experiments, (e.g. Noguchi et al., 1999), indirect observations using natural isotopes and numerical modelling (e.g. Dušek et al., 2012; Holko et al., 2011; McDonnell et al., 1991; McGuire and McDonnell, 2010; Šanda et al., 2014; Schneider et al., 2014), and multiple regression analysis of selected rainfallrunoff events (Hrnčír et al., 2010) have suggested that the dominant factors are shallow subsurface runoff, pipeflow of saturation excess overland flow, and rapid stream flow response to rainfall, often caused by pre-event water in the runoff in humid temperate catchments (Klaus et al., 2013).

Cultivated soils also exhibit similar runoff regimes. Cox et al. (2006) showed that the agricultural catchment described in their paper was much more likely to generate runoff than the forested catchment, due to rapid saturation of the tilled soil above the hardpan. Studies by Coquet et al. (2005), van Asch et 
al. (2001) and Verbist et al. (2007) confirmed the importance of compacted subsoil and the presence of lateral subsurface water flow in cultivated soils. They observed the low-permeable pan beneath wheel tracks, which caused local saturation in the seed bed where lateral flow was initiated during rainstorms. Similar runoff formation on a plot scale was observed by Bertolino et al. (2010). Despite evidence of subsurface flow processes, models based on the infiltration excess (overland flow) mechanism, e.g. the Soil Conservation Service (SCS) Curve Number method (CN) (USDA, 1983), are mainly employed when modelling the initiation of surface runoff and related processes, e.g. transport of soil particles and nutrients from cultivated soils.

Classical modelling approaches are often based on parameterization of a single conceptual model. Temporary variable runoff mechanisms within an individual catchment are rarely taken into consideration. This issue is well known, and has been identified by several authors, e.g. Beven (2001), Grayson et al. (1992), Schmocker-Fackel et al. (2007). The problem is to identify the prevailing mechanism for each rainfall-runoff event or annual period, especially when only limited data are available.

The aim of our paper is to examine the runoff dynamics of a small arable catchment, and to identify the prevailing runoff generation mechanisms. On the basis of observations, we test a hypothesis which assumes two dominant runoff mechanisms that prevail based on the state of the actual topsoil structure, vegetation cover and rainfall intensity and amount:

(a) freshly tilled soil contains stable macro-aggregates with hydraulically conductive inter-aggregate voids (preferential pathways). Water percolates through the preferential pathways towards a compacted and less conductive subsoil layer, where interflow is formed. In this case, subsurface runoff is the most common form of catchment drainage and results in an instant increase in discharge into the stream channel, with only limited sediment transport. The solid particles originate only from remobilisation of the deposited sediment in the stream channel. No infiltration excess surface runoff occurs under these conditions;

(b) during summer, when the topsoil may be compacted, the surface is often sealed and the number of preferential pathways is reduced. The bulk soil infiltration capacity is reduced and surface runoff may appear. The same process and effect can theoretically also be observed for loosened topsoil when there is an extreme and sufficiently long rainfall event, when its intensity exceeds the saturated hydraulic conductivity.

Our study investigates the following questions: (i) Do the temporary variable hydraulic properties of topsoil play a significant role in runoff generation? (ii) Where do suspended solid particles monitored in the discharge come from (from the field taken by surface runoff, or from the stream channel - resuspended particles from previous events) and can we use turbidity data as additional information for estimating the water pathways and the dominant runoff mechanism?

\section{STUDY AREA AND METHODS Study site}

The Nucice experimental catchment, which was established in 2011, is located in central Bohemia (Czech Republic), $30 \mathrm{~km}$ east of Prague, in a moderately hilly area at elevations of $382 \mathrm{~m}$ to $417 \mathrm{~m}$. The average elevation is $401 \mathrm{~m}$. The position of the basin closing profile is $49^{\circ} 57^{\prime} 49.230^{\prime \prime} \mathrm{N}, 14^{\circ} 52^{\prime} 13.242^{\prime \prime} \mathrm{E}$. The catchment has an area of $0.531 \mathrm{~km}^{2}$ (Fig. 1). The inclination of the hillslopes ranges from $1 \%$ to $12 \%$ with a mean slope of $3.9 \%$ (Fig. 2). The climate is humid continental, with average annual precipitation of $630 \mathrm{~mm}$, evapotranspiration of $500-550$ $\mathrm{mm}$, and mean annual air temperature $6^{\circ} \mathrm{C}$. The maximum mean

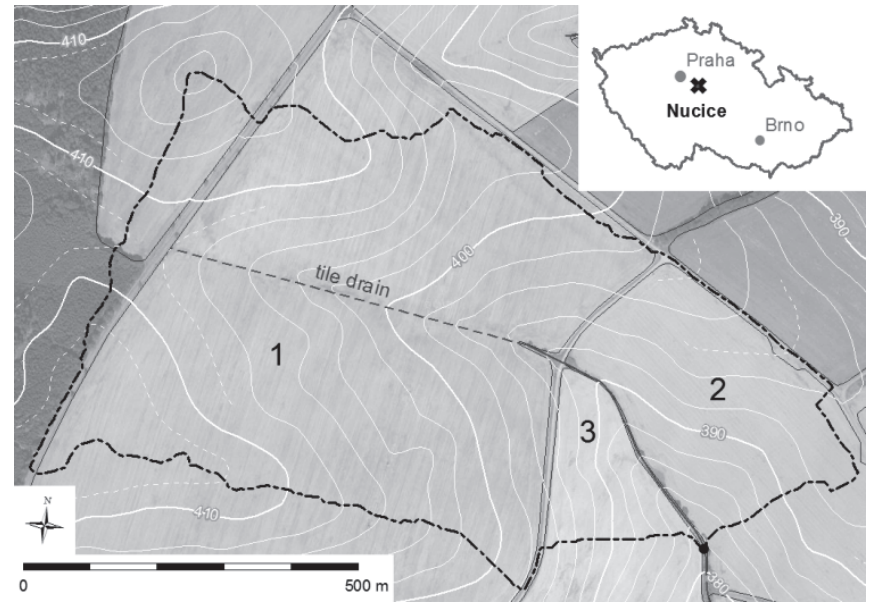

Fig. 1. Nucice catchment. Numbers denote the fields with different crops and tillage practices.

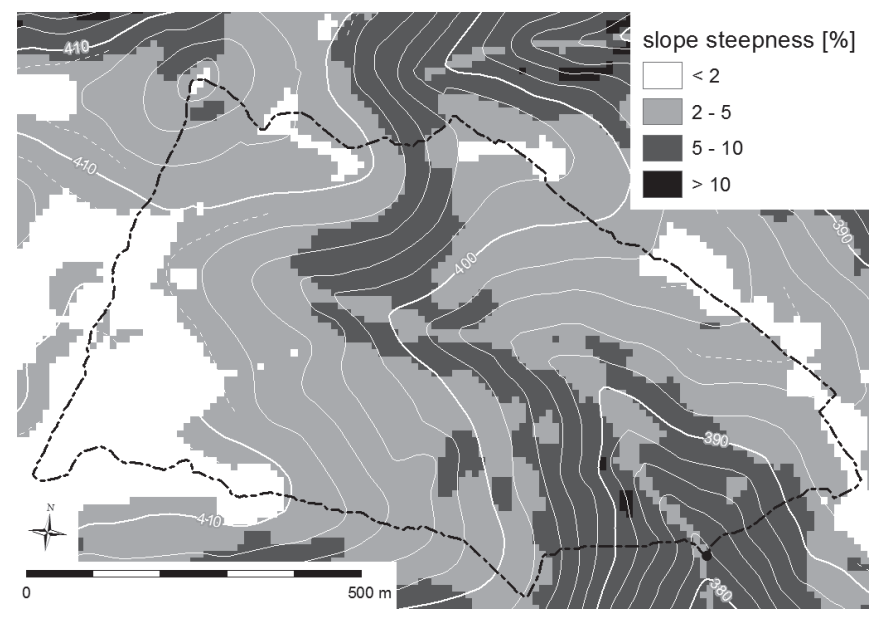

Fig. 2. Slope map of the Nucice catchment.

monthly rainfall occurs in July, and is delivered mostly by frontal and convective storms. The catchment was chosen for its uniform land use. $95.3 \%$ of the area is under active cultivation. The remaining area includes watercourse, sparse grasslands, riparian trees, shrubs and local roads. There is no urbanization or resident population.

The catchment is underlain by conglomerates, sandstone and siltstone. The soils are classified as Luvisols and Cambisols with a loamy Ap horizon (0.1-0.2 m deep) underlain by a silty and silty-clay B horizon. The content of clay particles in the topsoil is around $8 \%$. The soil has low inner aggregate (soil matrix) hydraulic conductivity, with measured values of approximately $10^{-8} \mathrm{~m} \mathrm{~s}^{-1}-2.3 \cdot 10^{-7} \mathrm{~m} \mathrm{~s}^{-1}$. The bulk topsoil saturated hydraulic conductivity $\left(K_{s}\right)$ ranges between $10^{-5} \mathrm{~m} \mathrm{~s}^{-1}$ and $10^{-4} \mathrm{~m} \mathrm{~s}^{-1}$, depending on the season. The $K_{s}$ is spatially variable, the higher values related to well developed and connected interaggregate voids. The divide between the topsoil and the subsoil is clearly observable via soil probing or penetration tests. The division between the uniform layers in Fields 1 and 2 was found at a depth of $0.14 \pm 0.02 \mathrm{~m}$. The subsoil in Field 3, which was conventionally tilled until 2013, was observed to be approximately $0.3 \mathrm{~m}$ in depth (Zumr et al., 2014). The subsoil is poor in structure, has a higher clay content and bulk density than the topsoil, and does not contain an extensive macropore network. The macropores that are present are formed by decayed roots and wormholes. They are mostly vertical, and are disconnected from each other. 
The catchment is divided into three fields cultivated by two farmers. Field $1\left(0.38 \mathrm{~km}^{2}\right)$ and Field $2\left(0.09 \mathrm{~km}^{2}\right)$ (Fig. 1) have been tilled conservatively since 2000 , with a combination of a compact disk harrow and a cultivator. The maximum depth of soil disturbance caused by tillage is $0.18 \mathrm{~m}$. A GPS guidance system with preserved parallel traffic lanes of $8 \mathrm{~m}$ span is implemented. The standard crop rotation includes mainly winter wheat, summer oats, winter rape and mustard. As conservatively tilled soils cover most of the catchment, the main focus in following text will be on these fields. The remaining western part of the basin (Field 3,0.03 $\mathrm{km}^{2}$ ) was tilled conventionally until 2012, with ploughing depth up to $0.3 \mathrm{~m}$, and in 2013 conservation tillage was introduced.

The catchment area is drained by a trained rural channel, which starts in the upper part of the catchment as a single tile drain. The total stream length is $1106 \mathrm{~m}$, from which $566 \mathrm{~m}$ is an open channel with a regular trapezoid cross section, stabilized by concrete tiles. The channel is approximately $1.2 \mathrm{~m}$ in depth and $0.6 \mathrm{~m}$ in width at the stream bed. The mean slope of the drainage line is $3 \%$. There are two culverts in the channel, each $0.8 \mathrm{~m}$ in diameter and about $8 \mathrm{~m}$ in length, but they do not have a significant effect on the water and sediment flow. The concrete lining is disturbed in some parts, and the stream bed is covered by sediment on the most of its length, which allows further sedimentation of solid particles and in-stream vegetation growth. The fields are cultivated right up to the stream banks with no buffer zones.

\section{Catchment instrumentation}

The experimental catchment is equipped with a standard meteorological station, where precipitation intensity, air temperature, humidity, wind speed and net solar radiation are monitored. The stream discharge is measured in an $\mathrm{H}$ flume with capacity up to $400 \mathrm{l} \mathrm{s}^{-1}$, using a calibrated rating curve and duplicate water level recording with a pressure probe (LMP 307, BD Sensors, Czech Republic) and an ultrasonic sensor (UGAGE T30UX, Banner, USA). A total suspended solids sensor (ViSolid 700 IQ, WTW, Germany) and a water sampling tube (3700 Full-size Portable Sampler, Teledyne ISCO, USA) are installed directly below the stream gauge in a small stilling basin. The recorded suspended sediment concentration is calibrated on the basis of the measured concentration of sediment in collected water samples, which are obtained during runoff events. The sediment yield is obtained through simultaneous measurement of the discharge and the suspended solids concentration. The groundwater level in the vicinity of the gauging station is monitored by means of two piezometers. The soil water regime is monitored by four multi-parameter water content reflectometers CS650 (Campbell Sci., UK), which are installed $20 \mathrm{~m}$ from the gauging station in Field no. 2 at a depth of $0.07 \mathrm{~m}, 0.12 \mathrm{~m}, 0.25 \mathrm{~m}$ and $0.4 \mathrm{~m}$. The probes record water content, bulk electrical conductivity and soil temperature. All measured data are collected and recorded automatically every five minutes during the growing season and every ten minutes during the rest of the year by a CR 1000 control and measurement datalogger (Campbell Sci., UK).

Since 2011, when the catchment was established, undisturbed $100 \mathrm{~cm}^{3}$ soil samples have been regularly taken to evaluate seasonal changes in the physical macroscopic properties of the topsoil, such as bulk density, actual moisture content and porosity. The highest sampling frequency is in the period from May until October, when rapid macrostructural changes are expected due to crop growth and agrotechnical operations. During each sampling campaign, approximately twenty soil cores from selected sites are taken and analysed.

\section{Complementary experiments related to runoff generation and sediment transport}

For a clear interpretation of the monitored rainfall-runoff events, we used the outcomes of previously conducted experiments: (a) plot scale rainfall simulations to investigate stormflow routing under various rainfall and field conditions (Strouhal et al., 2014); and (b) artificial flood wave experiments to estimate volume and resuspension of streambed sediment (Dostál et al., 2013).

Strouhal et al. (2014) presented a plot scale experiment aimed at observing and quantifying the components of runoff from cultivated soil during high-intensity rainfall. They used a mobile rainfall simulator equipped with four solenoidcontrolled nozzles (40WSQ FullJet, Spraying Systems Co) positioned $2.6 \mathrm{~m}$ above the soil. An inclined experimental plot $(8 \times 2 \mathrm{~m})$ was successively exposed to uniform simulated rainfall with intensity ranging from 23 to $64 \mathrm{~mm} \mathrm{~h}^{-1}$ and duration ranging from $1 \mathrm{~h}$ to $2.5 \mathrm{~h}$. These simulated rainfall parameters were selected to represent intensive rainfall events observed in the study locality, to generate surface runoff and to initiate soil erosion. Similar rainfall characteristics have been used is soil erosion studies elsewhere in Europe (e.g. Montenegro et al., 2013, Ries et al., 2013). The dynamics of surface and shallow subsurface runoff and the soil water regime at three soil depths were monitored. Various initial soil moisture conditions and vegetation stages; from cultivated fallow to stubble, delimited the simulations. Variable proportions of both monitored runoff components were observed in relation to rainfall intensity and duration, ranging from zero surface runoff to a distinct dominance of surface runoff. Both components reacted very dynamically to the precipitation: shallow subsurface runoff was formed first under all tested conditions on the given soil profile (a tilled loamy topsoil, compacted subsoil at a depth of $0.15 \mathrm{~m}$ ). In two simulations out of seven, both runoff components reached quasi steady-state conditions, and the subsurface discharge ranged from $30 \%$ to $40 \%$ of the direct runoff intensity. Even with the highest tested precipitation intensities, surface runoff always formed due to saturation excess of the topsoil, irrespective of the topsoil properties and crops.

The results of Strouhal et al. (2014) prove that lateral runoff through the shallow topsoil can easily cause a very quick increase of stream discharge. This runoff mechanism is not accompanied by significant soil erosion, but the increased stream flow causes a resuspension of streambed sediment and increased water turbidity.

It is difficult to distinguish the origin of the solid particles that are monitored at the gauging station. Therefore, Dostál et al. (2013) conducted six artificial flood experiments in the stream on the catchment to estimate the volume of resuspended stream bed sediments. The artificial waves (uniform discharge of $40 \mathrm{l} \mathrm{s}^{-1}$, volume of $16 \mathrm{~m}^{3}$ ) were introduced into the channel $450 \mathrm{~m}$ upstream of the gauging station. The aim was to monitor the flood wave transformation and the sediment transport within the channel in a way similar to Eder et al. (2014). On the basis of the results, it was concluded that the channel does contain sediment from previous erosion events that can be mobilized by even a slight increase of discharge. The peak discharge at the catchment outlet reached approximately $20 \mathrm{ls}^{-1}$ to $30 \mathrm{l} \mathrm{s}^{-1}$ (such values have been reached or exceeded five times in the last four years of natural runoff events observation) and duration of about 30 to 60 minutes, were able to carry the solid particles 
only a short distance. The hysteresis loop between discharge and sediment concentration was always clockwise, which implies that the sediment originates from the stream bed in the vicinity of the gauging station (Eder et al. 2010, Seeger et al. 2004). The highest suspended solids concentration was observed at the very beginning of the flood wave, when the maximum measured value reached almost $8 \mathrm{~g} \mathrm{l}^{-1}$ (corresponding to most of the natural flood events). The suspended solids flux reached as high as $900 \mathrm{~kg} \mathrm{~h}^{-1}$ at its peak, which is also comparable with recorded natural runoff events when no surface runoff was observed.

\section{Separation of the dominant runoff mechanisms}

In the Nucice catchment, three relevant runoff mechanisms are considered: (a) surface runoff due to infiltration excess, (b) shallow subsurface runoff in combination with pre-event water flow, (c) surface runoff due to saturation excess. Runoff due to deep water percolation causing a rise in the groundwater table is omitted, because the groundwater table is deep for most of the year, and its recharge is very slow due to the low hydraulic conductivity of the subsoil.

We aimed to identify the dominant runoff mechanism on the basis of rainfall, discharge, suspended solids and soil water regime data. To confirm the presence of surface runoff, we inspected the catchment after each event, when evidence of surface runoff was easy to document. The evidence of surface runoff is usually very clear; the most pronounced indicators are flattened riparian vegetation, flushed and wet man made shallow ditches, soil erosion resulting in suspension of particles and the development of rills. We quite often found small amounts of ponded or flowing water in wheel tracks. This runoff was neglected, because the area of wheel tracks was small and the tracks were not directly connected to the stream channel.

Each runoff mechanism produces greater or less runoff depending on actual catchment and rainfall conditions. Infiltration excess overland flow can be caused by very intensive rainfall, usually when the topsoil infiltration capacity is limited. This occurs when the topsoil is compacted or when the soil surface is sealed. A compacted topsoil has a low proportion of intraaggregate voids and macropores, which results in low porosity and high bulk density. We estimate that infiltration excess overland flow may take place when the mean topsoil saturated hydraulic conductivity is below about $10^{-5} \mathrm{~m} \mathrm{~s}^{-1}$. No values as low as this were measured at the studied location. A soil crust may appear in summer under sparse vegetation cover conditions and after a long dry period. Extensive surface sealing has not been observed in the catchment since 2011. The results from monitoring of the temporary variable physical properties of the topsoil in Nucice catchment show that the month in which infiltration excess overland flow is most likely to occur is August.

Interflow on an inclined subsoil layer may be initiated when the topsoil structure is well developed, with a high ratio of hydraulically conductive intra-aggregate pores and voids and when the subsoil has a significantly lower infiltration capacity. The rainfall intensity must exceed the infiltration capacity of the soil aggregates and the subsoil (soil matrix). Once interflow is initiated, the response of the stream discharge to changing precipitation patterns is very dynamic. Runoff via this mechanism causes the transport of few suspended solids (almost exclusively streambed particles are mobilized) and low runoff coefficients.

Saturation excess overland flow begins when precipitation is intense and long. Interflow causes water to accumulate in convergent parts of hillslopes. The water that does not fit into the topsoil pore space, begins to pond on the soil surface, thus forming return flow. Return flow is concentrated only in a part of the catchment, where soil erosion is initiated. These events are accompanied by high stream water turbidity and by a large quantity of soil particles transported from the fields. The state of the vegetation has to be taken into consideration.

We employed the monitored sediment fluxes at the catchment outlet as a measure of the dominant runoff mechanism and water flow pathways. Sediment concentration itself cannot serve as an unambiguous indicator. The sediment yield at the catchment outlet is only part of the total eroded soil particles, as a considerable quantity of the particles redeposit before reaching the stream. The soil erosion regime and sediment transport is very site specific. Verstraeten and Poesen (2001) identified catchment size as the most sensitive factor.

\section{RESULTS AND DISCUSSION}

From July 2011 to September 2014, approximately 40 rainfall-runoff events were recorded in the experimental catchment. Sixteen of these events with single and distinguishable peak hydrographs, with peak discharge greater than $4 \mathrm{l} \mathrm{s}^{-1}$ and with reliably recorded precipitation, runoff and turbidity were selected for an analysis of the runoff formation. The threshold of $4 \mathrm{~s} \mathrm{~s}^{-1}$ is twice the spring baseflow. A lower discharge usually mobilizes an amount of suspended solids too small to be estimated using the current setup. The difference between the peak discharge and the initial discharge had to be at least $21 \mathrm{~s}^{-1}$, and the suspended solids concentration had to reach a minimum of $1 \mathrm{~g} \mathrm{l}^{-1}$. Table 1 presents precipitation and runoff characteristics, and the runoff coefficient. The baseflow component was separated according to constant slope method. Characteristics of suspended solids are summarized in Table 2.

May to June is the part of the year when rainfall-runoff events were recorded most frequently (six events). This does not correspond to the temporal distribution of storm events that is assumed by soil erosion prediction methods (USLE Wischmeier, 1976), modified for conditions in the Czech Republic (Janeček et al., 2012), where the most frequent occurrence of storm events is expected in June-July. During the period of May-July are the soil properties most susceptible to surface runoff, because the bulk density is high and the topsoil porosity is low (Fig. 3). Both the infiltration capacity and the water retention capacity are therefore at their annual minimum. The distribution of rain events during the rest of the growing season is uniform, with a mean rate of about one episode per month.

\section{Surface runoff domination}

In 2013, two extreme events were recorded within a single month. The peak discharge on 2.6.2013 exceeded the maximum capacity of the flume, so the discharge and total flood volume were estimated from evidence of the maximum water depth in the channel above the flume. The peak discharge was calculated according to Chezy formula, the limbs of the storm hydrograph were extrapolated from the measured discharge which was recorded for values below $4001 \mathrm{~s}^{-1}$. The runoff was generated by a rainfall of $83.8 \mathrm{~mm}$ over a period ten hours. The soil had been almost saturated due to antecedent long precipitation of low intensity (three days of recurrent rainfall events with a maximum intensity of $4 \mathrm{~mm} \mathrm{~h}^{-1}$ resulting in $90 \%$ saturation of the soil profile to the monitored depth of $0.5 \mathrm{~m}$ ). The total specific runoff of $79 \mathrm{~mm}$, the runoff coefficient of $94 \%$ and the total suspended solids of 166 tons by far surpass all the other recorded events in our observations. Surface runoff, caused by 

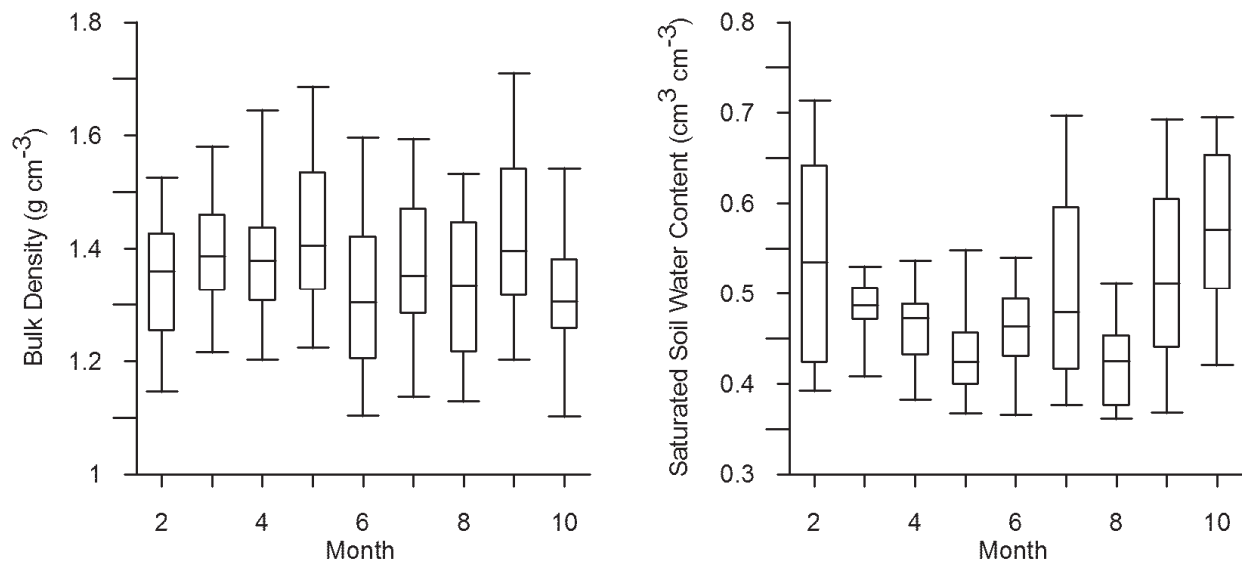

Fig. 3. Evaluation of the mean monthly soil bulk density (left) and saturated water content (right) of the cultivated topsoil as derived by regular soil sampling at the Nucice catchment from February until November between 2001 and 2014 (approx. 350 samples were analysed). Box and whisker plots depict minimum, maximum, median, first and third quartiles. There is a slight trend in increase in spring and decrease in late summer of the bulk density with its maximum in May to July. Saturated water content (which may be related to porosity) decreases in Spring and increases in Autumn with its minimum in May till August. High variability of soil physical parameters within the months are caused by spatial heterogeneity, crops growth, temporary variable soil organic matter content and agrotechnical operations.

Table 1. Rainfall and runoff characteristics of selected rainfall/runoff events recorded between 2011 and 2014 at the Nucice experimental catchment.

\begin{tabular}{|c|c|c|c|c|c|c|c|c|}
\hline \multirow[b]{2}{*}{$\begin{array}{c}\text { Event } \\
\text { no. }\end{array}$} & \multirow[b]{2}{*}{$\begin{array}{l}\text { Date } \\
\text { D.M.Y }\end{array}$} & \multicolumn{3}{|c|}{ Rainfall } & \multicolumn{3}{|c|}{ Runoff } & \multirow{2}{*}{$\begin{array}{c}\text { Runoff coefficient } \\
(\%)\end{array}$} \\
\hline & & $\begin{array}{l}\text { total } \\
(\mathrm{mm})\end{array}$ & $\begin{array}{l}\text { max. } 10 \text { min intensity } \\
\left(\mathrm{mm} \mathrm{h}^{-1}\right)\end{array}$ & $\begin{array}{l}\text { duration } \\
\text { (h) }\end{array}$ & $\begin{array}{l}\text { total } \\
\left(\mathrm{m}^{3}\right)\end{array}$ & $\begin{array}{l}\text { peak } \\
\left(1 \mathrm{~s}^{-1}\right)\end{array}$ & $\begin{array}{c}\text { specific } \\
(\mathrm{mm})\end{array}$ & \\
\hline 1 & 11.7 .2011 & 22.4 & 27 & 2.5 & 151 & 9.2 & 0.3 & 1.3 \\
\hline 2 & 5.9.2011 & 23.4 & 25 & 5 & 170 & 7.6 & 0.3 & 1.5 \\
\hline 3 & 3.8 .2012 & 25 & 34 & 3 & 153 & 8.8 & 0.3 & 1.2 \\
\hline 4 & 26.8.2012 & 15 & 20 & 1.5 & 23 & 4.1 & 0.1 & 0.3 \\
\hline 5 & 9.5 .2013 & 11.2 & 33.6 & 0.7 & 344 & 132 & 0.7 & 6.3 \\
\hline 6 & 26.5.2013 & 7.4 & 14.4 & 2 & 23 & 6.4 & 0.1 & 0.7 \\
\hline 7 & 27.5.2013 & 8.2 & 8.4 & 2 & 266 & 23.5 & 0.5 & 6.7 \\
\hline 8 & 2.6.2013 & 83.8 & 46 & 10 & $39500^{\mathrm{a}}$ & $900^{\mathrm{a}}$ & $79^{a}$ & $94^{\mathrm{a}}$ \\
\hline 9 & 25.6.2013 & 81.4 & 8.4 & 8 & 5100 & 117 & 10.2 & 13 \\
\hline 10 & 4.8.2013 & 15.1 & 36 & 2.5 & 34 & 6.3 & 0.1 & 0.5 \\
\hline 11 & 5.2 .2014 & 20.4 & 49 & 4 & 200 & 10.6 & 0.4 & 2.0 \\
\hline 12 & 24.5.2014 & 18.7 & 30 & 4 & 177 & 15.5 & 0.2 & 1.9 \\
\hline 13 & 27.5.2014 & 8.2 & 40 & 0.75 & 65 & 7.3 & 0.1 & 1.6 \\
\hline 14 & 29.5.2014 & 19 & 17.4 & 6 & 55 & 29.5 & 0.1 & 0.6 \\
\hline 15 & 21.7.2014 & 40.2 & 66.6 & 2.5 & 251 & 64 & 0.5 & 1.2 \\
\hline 16 & 14.9.2014 & 12.2 & 30 & 5 & 380 & 15.7 & 0.8 & 6.2 \\
\hline
\end{tabular}

${ }^{a}$ The capacity of the H-flume was exceeded, the values are estimated according to observed aftermath of the flooding (flattened vegetation) in the channel.

Table 2. Summary of suspended sediment data as recorded at the gauging station.

\begin{tabular}{|c|c|c|c|c|c|}
\hline $\begin{array}{c}\text { Event } \\
\text { no. }\end{array}$ & $\begin{array}{l}\text { Date } \\
\text { D.M.Y }\end{array}$ & $\begin{array}{l}\text { Total suspended } \\
\text { solids } \\
(\mathrm{kg})\end{array}$ & $\begin{array}{l}\text { Max. suspended } \\
\text { solids } \\
\text { concentration } \\
\left(\mathrm{g} \mathrm{l}^{-1}\right)\end{array}$ & $\begin{array}{l}\text { Max. suspended } \\
\text { solids flux } \\
\left(\mathrm{kg} \mathrm{h}^{-1}\right)\end{array}$ & $\begin{array}{l}\text { Runoff indication } \\
\text { index } \\
\left(\mathrm{kg} \mathrm{h}^{-1}\right)\end{array}$ \\
\hline 1 & 11.7 .2011 & 51 & 2.1 & 31 & 20 \\
\hline 2 & 5.9.2011 & 54 & 0.6 & 15 & 11 \\
\hline 3 & 3.8 .2012 & 120 & 2.7 & 83 & 40 \\
\hline 4 & 26.8.2012 & 13 & 2 & 81 & 8 \\
\hline 5 & 9.5 .2013 & $4600^{\mathrm{a}}$ & $>26^{\mathrm{a}}$ & $12500^{\mathrm{a}}$ & 6600 \\
\hline 6 & 26.5.2013 & 28 & 2 & 40 & 14 \\
\hline 7 & 27.5 .2013 & 400 & 2.4 & 194 & 199 \\
\hline 8 & 2.6.2013 & $166000^{\mathrm{a}}$ & $>26^{\mathrm{a}}$ & $52000^{\mathrm{a}}$ & 16600 \\
\hline 9 & 25.6 .2013 & 6300 & 3 & 522 & 783 \\
\hline 10 & 4.8 .2013 & 34 & 1.6 & 31 & 14 \\
\hline 11 & 5.2 .2014 & 340 & 4.3 & 132 & 85 \\
\hline 12 & 24.5 .2014 & 100 & 5 & 72 & 25 \\
\hline 13 & 27.5 .2014 & 190 & 7.4 & 171 & 257 \\
\hline 14 & 29.5.2014 & 990 & 4.3 & 282 & 165 \\
\hline 15 & 21.7 .2014 & $2500^{\mathrm{a}}$ & $>26^{\mathrm{a}}$ & $200^{\mathrm{a}}$ & 1000 \\
\hline 16 & 14.9 .2014 & 530 & 2.9 & 125 & 106 \\
\hline
\end{tabular}

${ }^{a}$ records when the measurable turbidity range was exceeded, the total suspended solids and fluxes are estimated values

${ }^{\mathrm{b}}$ runoff indication coefficient is a ratio between total suspended solids and precipitation duration (Equation 1). 
the saturation excess of the soil profile, through the thalweg above the open stream channel and within wheel tracks throughout the whole catchment, was observed during a site inspection. The peakflow return period was estimated to be approximately 50 years from data available from the Czech Hydrometeorological Institute.

Examples of hydrographs and sedigraphs with the dominant surface runoff mechanism are shown in Fig. 4. The event from 9.5.2013 (event 5) was the result of a short rainfall with high intensity. The sediment flux of solid particles leaving the catchment reached over ten tons per hour at its peak, which must include a contributing soil eroded from the adjacent fields.

The discharge recorded on 25.6.2013 (event 9) with a peak discharge of $117 \mathrm{~s} \mathrm{~s}^{-1}$ was also partly caused by saturated excess overland flow. Surface runoff was initiated only in the convergent areas close to the stream and the thalweg due to topsoil saturation excess, and in compacted wheel tracks. The precipitation intensity was below the topsoil saturated hydraulic conductivity, but parts of the catchment were still saturated from the previous rainfall. The event came after the extreme event (8), followed by minor recurrent rainfall, and was initiated by a long period of low-intensity precipitation. The fine-grained stream bed sediment close to the gauge was immediately mobilized by the first raindrops. The maximum suspended solids flux only reached $500 \mathrm{~kg} \mathrm{~h}^{-1}$. Due to the well established crops (wheat on Fields 1 and 2, mustard on Field 3) and the low precipitation intensity, no significant soil erosion began. The outflowing suspended solids are attributed to resuspended sediments from the stream bed deposited during the previous event.

\section{Subsurface runoff domination}

In twelve of the sixteen recorded events, no surface runoff was observed. Nevertheless, the reaction of the stream flow to the precipitation events was very rapid (Fig. 5). Subsurface runoff always initiated very quickly and reacted to small variations in rainfall intensity. Similar runoff regime on cultivated soils with fragipan layer was also observer by e.g. Dahlke et al. (2011), Klaus et al. (2013) or Steenhuis et al. (1988).
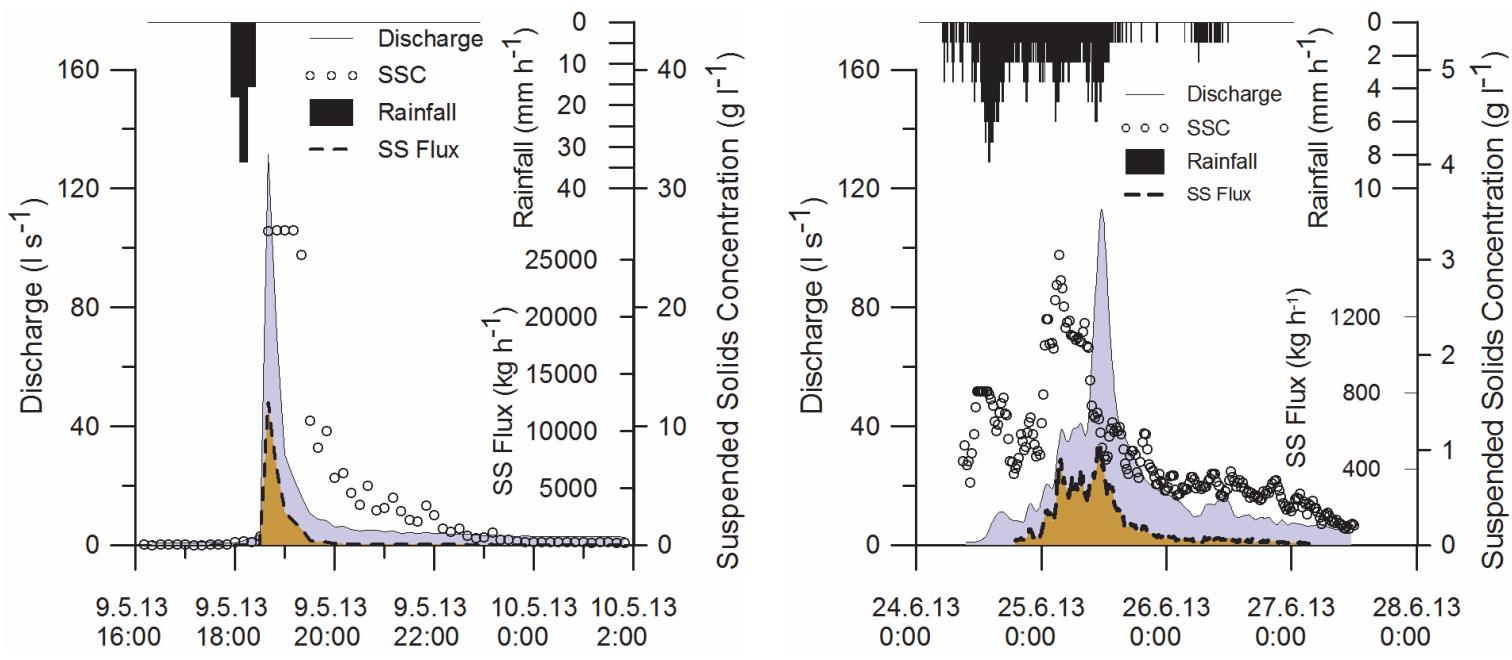

Fig. 4. Examples of hydrographs and sedigraphs of the events when overland flow contributed to the catchment outflow. The values of SS (suspended sediments) flux and discharge are higher by orders of magnitude than in case of no overland flow contribution (see Fig. 5); SSC is the suspended sediment concentration.


Fig. 5. Examples of rainfall outflow episodes when shallow subsurface runoff was the principle pathway of runoff to the stream. 

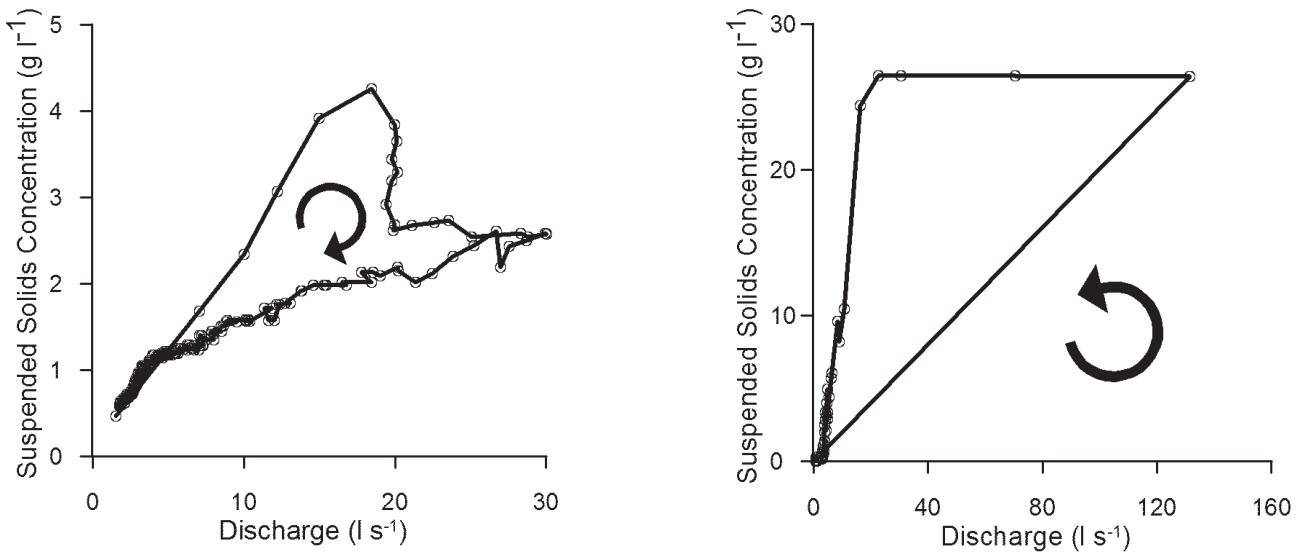

Fig. 6. Hysteretic loops indicating where the sediment originates. Example of domination of bed load sediment transport is on the left (event 14) and eroded particles from the arable fields on the right (event 5).

The maximum discharge initiated by subsurface runoff of almost $30 \mathrm{l} \mathrm{s}^{-1}$ (note the value similar to the peak flows during the artificial flood experiments) was recorded on 29.5.2014. In the course of the remaining events, the maximum suspended sediment concentrations did not exceed $8 \mathrm{~g} \mathrm{l}^{-1}$ (as in the case of the artificial flood experiments).

The sediment concentration rose instanteously with the approaching flood wave, and the maximum turbidity was recorded approximately at the same time as the peak discharge, or a little before. In the event of a long peak discharge or double peaking, sediment concentration usually reached the maximum value within the first peak (Fig. 5 - 23.5.2014, 14.9.2014). As the baseflow was very low in all cases, the flood wave velocity and the celerity were almost equal. Most of the recorded hysteresis loops of discharge versus suspended solids concentration showed a clockwise direction (Fig. 6). This suggests that the main source of the sediment yield deposited on the stream bed close to the gauging station (Lefrançois et al., 2007). Very finegrained deposited sediment also came from the tile drain above the open channel. As the stream channel is fortified with concrete tiles, we do not suppose that the stream bank or stream bed failures contributed significantly to the total quantity of transported solid particles. On a recession limb of a hydrograph, the sediment concentration decreases. The reason is that mobile fine-grained particles are quickly flushed from the stream bed, and the flowing water does not have sufficient kinetic energy to carry heavier particles over a long distance (Dostál et al., 2013; Eder et al. 2014).

\section{Analysis of the suspended solids regime}

The events show reasonable range in the total delivered suspended solids and in the maximum concentrations. During most of the rainfall episodes, irrespective of precipitation intensity, storm duration or hydrograph characteristics, the maximum suspended solids concentration did not reach values higher than $3 \mathrm{~g}^{-1}$.

We found no clear correlation between the runoff mechanism and the discharge or suspended solids regime. High turbidity and high peak discharge were also recorded during events when surface runoff was not observed. A better indicator than discharge, turbidity or total sediment yield is the maximum suspended solids flux averaged by ten-minute intervals. The values during events 5 and 8 (Table 2) were higher by orders of magnitude than during other episodes, or than the values measured during artificial flooding experiments (Dostál et al., 2013).
These fluxes cannot be reached without influx of eroded particles from the cultivated fields, unless the high turbidity is caused by massive stream bank or stream bed failures (which were not observed here).

Another tested indicator of the prevailing runoff mechanism was the newly-introduced runoff indication index $R\left(\mathrm{~kg} \mathrm{~h}^{-1}\right)$, which is the ratio between the total sediment yield $S S_{\text {tot }}(\mathrm{kg})$ and the duration of the precipitation that caused the increase in discharge $T_{\text {prec }}(\mathrm{h})$ :

$$
R=\frac{S S_{\text {tot }}}{T_{\text {prec }}}
$$

This index characterizes not just the short-term peak sediment fluxes but the net response of the catchment to the rainfall. The calculated runoff indication indexes range from $8 \mathrm{~kg} \mathrm{~h}^{-1}$ (event 4) to $16600 \mathrm{~kg} \mathrm{~h}^{-1}$ (event 8). Episodes 5 and 8 have significantly higher $\mathrm{R}$ than the other events. Events 9 and 15, with $\mathrm{R}$ around $1000 \mathrm{~kg} \mathrm{~h}^{-1}$, are the events when surface runoff most likely also occurred. Lower values are partly caused by dense vegetation (wheat) resulting in decreased soil erosion. During the events where lower $R$ was calculated, subsurface runoff was prevalent. The runoff indication index does not depend directly on the peak discharge, turbidity or runoff coefficient, as is shown in Fig. 7, where the size of the circles represents the maximum turbidity and the peak discharge.

The hysteresis loops of the suspended solids concentration and discharge corresponded in most cases to the dominant runoff mechanism. In the case of subsurface runoff, when the sediment fluxes were smaller, the loops had a clockwise direction. The surface runoff causes significantly higher sediment loads, so the initial solids flux, which is caused by the stream bed sediments, is lower than the flux when the particles from the adjacent fields arrive. The direction of the loop is anticlockwise. Examples of both scenarios are shown in Fig. 6.

\section{CONCLUSIONS}

Sixteen rainfall-runoff events that were recorded in a small agricultural catchment were evaluated in order to identify the major runoff mechanisms and their implication for soil erosion and sediment transport from the catchment. Most of the events that were initiated by precipitation of various intensities and durations resulted in a rapid increase of stream discharge with no surface runoff in the catchment (as documented by field survey). 

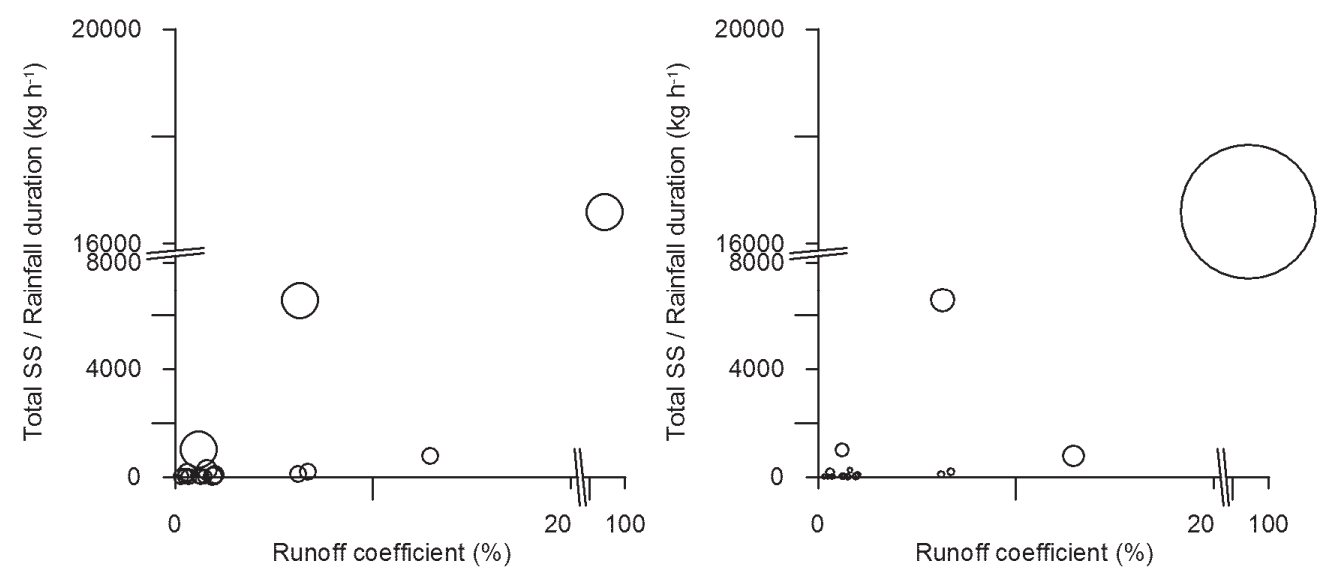

Fig. 7. Surface runoff indicator expressed as an index - ratio between total sediment yield and duration of rainfall. Circle sizes denote maximum suspended solids concentration (left) and peak stream discharge (right).

The shallow subsurface runoff taking place within the topsoil layer is the most common mechanism.

Monitoring of the topsoil physical properties shows seasonal variability, but we have not identified a clear relationship between actual soil conditions and dominant runoff formation mechanism in the studied catchment. The surface runoff, mostly saturated excess driven, occurs only seldom and was caused by heavy rainfall in combination with high antecedent catchment saturation. The topsoil was never compacted to such a level that infiltration excess overland flow could dominate. In the period of four years for which the catchment has been monitored, two extreme events have been observed, in which surface runoff caused by topsoil saturation excess overland flow was clearly dominant.

We identified the prevailing runoff mechanism (subsurface or surface runoff) indirectly based on the monitoring of the suspended solids regime at the catchment outlet. We employed analysis of the suspended sediment flux, the newly-introduced runoff indication index (the ratio between the rainfall duration and the total sediment yield), and direction of the dischargeturbidity hysteresis loops. We recognize these values to be reflective indicators of the runoff mechanism, even though the thresholds are very site specific, depend on actual state of the vegetation cover, and cannot be generalized. During most runoff events the recorded sediment loads came from the fine sediment deposited on the stream bed which indicates the predominance of subsurface runoff.

Acknowledgement. We thank our colleagues Josef Krása, Václav David, Petr Koudelka, Luděk Strouhal for their great help at the catchment. Robin Healey and Philip Moravcik are acknowledged for the English proofreading. This paper was prepared in the framework of Czech Science Foundation postdoctoral project GP13-20388P and Ministry of Agriculture project NAZV QJ1230056.

\section{REFERENCES}

Alaoui, A., Lipiec, J., Gerke, H.H., 2011. A review of the changes in the soil pore system due to soil deformation: a hydrodynamic perspective. Soil Till. Res., 115, 1-15.

Bachmair, S., Weiler, M., Troch, P.A., 2012. Intercomparing hillslope hydrological dynamics: spatio-temporal variability and vegetation cover effects. Water Resour. Res., 48, W05537. doi: 10.1029/2011wr011196.
Bertolino, A.V.F.A., Fernandes, N.F., Miranda, J.P.L., Souza, A.P., Lopes, M.R.S., Palmieri, F., 2010. Effects of plough pan development on surface hydrology and on soil physical properties in Southeastern Brazilian Plateau. J. Hydrol., 393, $1-2,94-104$.

Beven, K., 2001. How far can we go in distributed hydrological modelling? Hydrol. Earth Syst. Sci, 5, 1-12.

Birkel, C., Soulsby, C., Tetzlaff, D., 2011. Modelling catchment-scale water storage dynamics: reconciling dynamic storage with tracer-inferred passive storage. Hydrol. Process., 25, 25, 3924-3936.

Coquet, Y., Simunek J., Coutadeur, C., van Genuchten, M.Th., Pot, V., Roger-Estrade, J. 2005. Water and solute transport in a cultivated silt loam soil: 1 . Field observations. Vadose Zone J., 4, 3573-3586.

Cox, C.A., Sarangi, A., Madramootoo, C.A., 2006. Effect of land management on runoff and soil losses from two small watersheds in St Lucia. Land Degrad. Dev., 17, 1, 55-72.

Dahlke, H.E., Easton, Z.M., Lyon, W.L., Walter, M.T., Destouni, G., Steenhuis, T.S., 2011. Dissecting the variable source area concept - subsurface flow pathways and water mixing processes in a hillslope. J. Hydrol., 420-421, 125141.

Dorioz, J.M., Ferhi, A., 1994. Nonpoint pollution and management of agricultural areas - phosphorus and nitrogen transfer in an agricultural watershed. Water Res., 28, 2, 395410.

Dostál, T., Zumr, D., Rosendorf, P., Strauss, P., Ř́iha, V., 2013. Experimental assessment of transformation rate of flood wave in trained stream channel of small water course. Vodní hospodářství, 11, 373-378. (In Czech.)

Dušek, J., Vogel, T., Šanda, M., 2012. Hillslope hydrograph analysis using synthetic and natural oxygen-18 signatures. J. Hydrol., 475, 415-427.

Eder, A., Strauss, P., Krueger, T., Quinton, J.N., 2010. Comparative calculation of suspended sediment loads with respect to hysteresis effects (in the Petzenkirchen catchment, Austria). J. Hydrol., 389, 1-2, 168-176.

Eder, A., Exner-Kittridge, M., Strauss, P., Bloeschl, G., 2014. Re-suspension of bed sediment in a small stream - results from two flushing experiments. Hydrol. Earth Syst. Sci., 18, 3, 1043-1052.

Grayson, R.B., Moore, I.D., McMahon, T.A., 1992. Physically based hydrologic modeling. 1. A terrain-based model for investigative purposes. Water Resour. Res., 28, 10, 2639-2658. 
Holko, L., Kostka, Z., Šanda, M., 2011. Assessment of frequency and areal extent of overland flow generation in a forested mountain catchment. Soil Water Res., 6, 1, 43-53.

Hrnčíř, M., Šanda, M., Kulasová, A., Císlerová, M., 2010. Runoff formation in a small catchment at hillslope and catchment scales. Hydrol. Process., 24, 16, 2248-2256.

Janeček M., Květoň V., Kubátová E., Kobzová D., 2012. Differentiation and regionalization of rainfall erosivity factor values in the Czech Republic. Soil Water Res., 7, 1-9.

Jones, J., 1997. Pipeflow contributing areas and runoff response. Hydrol. Process., 11, 1, 35-41.

Klaus, J., Zehe, E., Elsner, M., Kulls, C., McDonnell, J.J., 2013. Macropore flow of old water revisited: experimental insights from a tile-drained hillslope. Hydrol. Earth Syst. Sci., 17, 103-117.

Kovats, R.S., Valentini, R., Bouwer, L.M., Georgopoulou, E., Jacob, D., Martin, E., Rounsevell, M., Soussana, J.F., 2014. Europe. In: Barros, V.R., Field, C.B., Dokken, D.J., Mastrandrea, M.D., Mach, K.J., Bilir, T.E., Chatterjee, M., Ebi, K.L., Estrada, Y.O., Genova, R.C., Girma, B., Kissel, E.S., Levy, A.N., MacCracken, S., Mastrandrea, P.R., White, L.L. (Eds.): Climate Change 2014: Impacts, Adaptation, and Vulnerability. Part B: Regional Aspects. Contribution of Working Group II to the Fifth Assessment Report of the Intergovernmental Panel on Climate Change. Cambridge University Press, Cambridge, United Kingdom and New York, NY, USA, pp. 1267-1326.

Lefrançois, J., Grimaldi, C., Gascuel-ODoux, C., Gilliet, N., 2007. Suspended sediment and discharge relationships to identify bank degradation as a main source on small agricultural catchments. Hydrol. Process., 21, 2923-2933.

McDonnell, J.J., Stewart, M.K., Owens, I.F., 1991. Effect of catchment-scale subsurface mixing on stream isotopic response. Water Resour. Res., 27, 12, 3065-3073.

McGuire, K.J., McDonnell, J.J., 2010. Hydrological connectivity of hillslopes and streams: characteristic time scales and nonlinearities. Water Resour. Res., 46, W10543. doi: 10.1029/2010wr009341.

Montenegro, A.A.A., Abrantes, J.R.C.B., de Lima, J.L.M.P, Singh, V.P., Santos, T.E.M., 2013. Impact of mulching on soil and water dynamics under intermittent simulated rainfall. CATENA, 109, 139-149.

Noguchi, S., Tsuboyama, Y., Sidle, R.C., Hosoda, I., 1999. Morphological characteristics of macropores and the distribution of preferential flow pathways in a forested slope segment. Soil Sci. Soc. Am. J., 63, 5, 1413-1423.

Pare, N., Andrieuxa, P., Loucharta, X., Biarnesb, A., Voltza M., 2011. Predicting the spatio-temporal dynamic of soil surface characteristics after tillage. Soil Till. Res., 114, 2, 135-145.

Ries, J.B., Iserloh, T., Seeger, M., Gabriels, D., 2013. Rainfall simulations - constraints, needs and challenges for a future use in soil erosion research. Zeitschrift für Geomorphologie, 57, 1, 1-10.

Roulier, S., Angulo-Jaramillo, R., Bresson, L.M., Auzet, A.V., Gaudet, J.P., Bariac, T., 2002. Water transfer and mobile water content measurement in a cultivated crusted soil. Soil Sci., 167, 3, 201-210.
Šanda, M., Vitvar, T., Kulasová, A., Jankovec, J., Císlerová, M., 2014. Run-off formation in a humid, temperate headwater catchment using a combined hydrological, hydrochemical and isotopic approach (Jizera Mountains, Czech Republic). Hydrol. Process., 28, 8, 3217-3229.

Schmocker-Fackel, P., Naef, F., Scherrer, S., 2007. Identifying runoff processes on the plot and catchment scale. Hydrol. Earth Syst. Sci., 11, 2, 891-906.

Schneider, P., Pool, S., Strouhal, L., Seibert, J., 2014. True colors - experimental identification of hydrological processes at a hillslope prone to slide. Hydrol. Earth Syst. Sci., 18, 875-892.

Seeger, M., Errea, M.P., Beguería, S., Arnáez, J., Martí, C., García-Ruíz, J.M., 2004. Catchment soil moisture and rainfall characteristics as determinant factors for discharge/suspended sediment hysteretic loops in a small headwater catchment in the Spanish Pyrenees. J. Hydrol., 288, 299-311.

Steenhuis, T.S., Richard, T.J., Parlange, M.B., Aburime, S.O., Geohring, L.D., Parlange, J.Y., 1988. Preferential flow influences on drainage of shallow sloping soils. Agr. Water Manage., 14, 1-4, 137-151.

Strouhal, L., Zumr, D., David, V., Kavka, P., 2014. Experimental identification and numerical modelling of subsurface runoff on the compacted subsoil. In: Brych, K., Tesař, M. (Eds.): Hydrology of a Small Catchment 2014. Institute of Hydrodynamics AS CR, Prague, pp. 441-448. (In Czech.)

USDA, Soil Conservation Service, 1983. Computer Programs for Project Formulation - Hydrology, Technical Release 20, Washington, DC.

Van Asch, T., Van Dijck, S., Hendriks, M.R., 2001. The role of overland flow and subsurface flow on the spatial distribution of soil moisture in the topsoil. Hydrol. Process., 15, 12, $2325-2340$.

Verbist, K., Cornelis, W.M., Schiettecatte, W., Oltenfreiter, G., Van Meirvenne, M., Gabriels, D., 2007. The influence of a compacted plow sole on saturation excess runoff. Soil Till. Res., 96, 1-2, 292-302.

Verstraeten, G., Poesen, J., 2001. Factors controlling sediment yield from small intensively cultivated catchments in a temperate humid climate. Geomorphology, 40, 1-2, 123144.

Whipkey, R.Z., 1965. Subsurface stormflow from forested slopes. Bull. Int. Assoc. Sci. Hydrol., 10, 2, 74-85.

Wischmeier, W.H., 1976. Use and misuse of universal soil loss equation. J. Soil Water Conserv., 31, 1, 5-9.

Zumr, D., Devátý, J., Klípa, V., Kavka, P., Dušek, J., Dostál, T., 2014. Runoff and soil erosion formation on small arable catchment. In: de Lima, M.I.P., de Lima, J.L.M.P. (Eds.): Book of Abstracts of the 15th Biennial Conference of Euromediterranean Network of Experimental and Representative Basins. Department of Civil Engineering of the University of Coimbra, Coimbra, Portugal, p. 41.

Received 8 November 2014 Accepted 23 February 2015

Note: Colour version of Figures can be found in the web version of this article. 